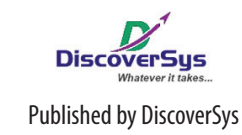

Published by DiscoverSys

\section{The role of social media support as public health intervention strategy in Indonesia}

\author{
Pande Putu Januraga*
}

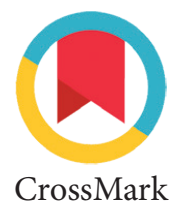

Public Health Postgraduate Program Udayana University
*Correspondence to:

Pande Putu Januraga, Public Health Postgraduate Program Udayana University

januraga@unud.ac.id
Internet is a brand new lifestyle that plays a significant role in influencing people's life. ${ }^{1}$ Internet could provide multifariousness of possibilities for communication, entertainment and dealing with every day-life requirements that makes the role of internet becomes wider. Furthermore, because of its essential function, a study on internet addiction revealed that the technology could make people believe that they could not live without it. ${ }^{2}$

Based on survey conducted by e-Marketer, more than 2.5 billion people were registered as active internet users worldwide in 2013 and the number is significantly increasing every year. In 2018 , the projection of internet users could reach 3.6 billion and about $71 \%$ of those users will access internet regularly this year. The country with the most number of internet users, who at least accessing internet once a month, in 2014 was China (644 million) then followed by USA, India, Brazil, Japan and Indonesia. ${ }^{3}$

As the fourth most populous country in the world, ${ }^{4}$ internet users in Indonesia have reached 83.7 million in 2014 and over the next three years it increased more than $34 \%$. It is predicted that the number of people who access internet at least once a month will be 123 million and will surpass the number of internet users in Japan by 2018 . One of the driven factors for the boost is the usage of mobile devices such as smartphone and tablet in developing countries including Indonesia. With very tight market competition from local and international producers, the devices have become more affordable and therefore accessible. ${ }^{5}$

Social network is the most common and favored site accessed by internet users worldwide with Facebook ranked as the most accessed platform, almost 1.5 billion people will log in in Facebook in 2017 , or more than $60 \%$ of total social network users. Furthermore, in 2017, 87\% of Facebook users will access it through mobile devices. ${ }^{6}$ The same figure also happens in Indonesia, about 95\% of internet users accessed social media or social network in 2013 with 65 million active Facebook users. ${ }^{7}$ Other social media and online messenger applications that actively used by internet users in Indonesia are Instagram, Twitter, Line, and WhatsApp.

While originally social media was developed to help people connect each other, its massive popularity introduces not only benefits but also brings harm to its users. Excessive use of social media could lead its users to addiction followed by mental health problems such as personality neuroticism and psychoticism. ${ }^{1}$ Furthermore, some studies have also concluded that worse internet addiction is strongly related to many psychological issues such as depression, anxiety, social-isolation, sleep problem and the worst was able to lead people to have reduced self-reported immune function. ${ }^{8,9}$ However, in spite of the fact that the social media could introduce health problems, because of large users, it has potential to be utilized for improving health status of people. Some studies revealed that internet/social media support could be effectively utilized for health purpose, for example to be used for consumer information health services, health promotion and education, social support for patients who had chronic diseases, adherence of treatment, health monitoring and reporting etc. ${ }^{10-13}$

With the growing users and different platforms available, Indonesia has big opportunity to use internet and social media to support any existing traditional or conventional health intervention approaches. However, still limited studies available to provide good evidence on the usefulness of internet and social media for health purposes in Indonesia. This mainly due to the limited funds and resources available to conduct qualified study with advanced methods for measuring social media effectiveness. One study that might lead us for better studies in Indonesia is the innovative health purposes using internet implemented in the latest study protocol developed by Arjadi et al. ${ }^{14}$ The study aimed to use internet based behavioral activation intervention for depression in Indonesia. Even though the study has not produced any preliminary result yet, the study is claimed as the first study in Indonesia that examined the effectiveness of internet based intervention specifically for depression using randomized controlled trial (RCT) research design. It shows that internet and social media are also able to be used as platform to conduct 24/7 and intensive health support for people in the situation that they are possibly not able to meet with health providers. The other potential usage of the internet technology could be implemented by online messages applications in mobile devices. The text messages could be indispensable in the situation that people need to be reminded, for example in 
adherence of hypertension and antiretroviral treatment. ${ }^{15,16}$ Furthermore, social media platforms are also possibly used to maintain healthy behavior and lifestyle, for example in diabetes case management. ${ }^{17}$

Finally, with the growing and high number of internet and social media users, it could be concluded that Indonesia is a potential country for the development of internet-social media based health intervention. ${ }^{18}$ Currently, there are abundant programs and/or campaign using internet and social media based as platforms for health information and promotion, however most of them were developed without proper evaluation design to measure its effectiveness. Universities and research centers in the country could become a potential partner for any developers for developing programs and/or campaigns that utilize internet and social media in standardized and scientific ways.

\section{REFERENCES}

1. Ge Y, Se J and Zhang J. Research on Relationship Among Internet-Addiction, Personality Traits and Mental Health of Urban Left-Behind Children. Global Journal of Health Science; 2015; 7: 60-9.

2. Brand M, Young KS and Laier C. Prefrontal Control and Internet Addiction: A Theoretical Model and Review of Neuropsychological and Neuroimaging Findings. Frontiers in Human Neuroscience; 2014; 8: 375.

3. Kominfo. Pengguna Internet Indonesia Nomor Enam Dunia. Jakarta: Kementerian Komunikasi dan Informatika Republik Indonesia; 2014.

4. PRB. 2015 World Population Data Sheet with a special focus on women's empowerment. Population Reference Burea; 2015.

5. Rahmayani I. Indonesia Raksasa Teknologi Digital Asia. Jakarta: Kementerian Komunikasi dan Informatika Republik Indonesia; 2015.

6. eMarketer. Worldwide Social Network Users: eMarketer's Estimates and Forecast for 2016-2021. eMarketer; 2017.

7. Kominfo. Penyediaan Layanan Aplikasi dan/atau Konten melalui Internet (Over the Top). Indonesia: kominfo.go.id; 2016.
8. Bergmark KH, Bergmark A and Findahl O. Extensive Internet Involvement-Addiction or Emerging Lifestyle? International Journal of Environmental Research and Public Health; 2011; 8: 4488-501.

9. Reed P, Vile R, Osborne LA, Romano M and Truzoli R. Problematic Internet Usage and Immune Function. PLoS ONE; 2015; 10: e0134538.

10. Beck F, Richard J-B, Nguyen-Thanh V, Montagni I, Parizot I and Renahy E. Use of the Internet as a Health Information Resource Among French Young Adults: Results From a Nationally Representative Survey. Journal of Medical Internet Research. 2014; 16: e128.

11. Bujnowska-Fedak MM. Trends in the use of the Internet for health purposes in Poland. BMC Public Health; 2015; 15: 194.

12. Kalckreuth S, Trefflich F and Rummel-Kluge C. Mental health related Internet use among psychiatric patients: a cross-sectional analysis. BMC Psychiatry; 2014; 14: 368.

13. Hilliard ME, Sparling KM, Hitchcock J, Oser TK and Hood KK. The Emerging Diabetes Online Community. Current diabetes reviews; 2015; 11: 261-72.

14. Arjadi R, Nauta MH, Scholte WF, et al. Guided Act and Feel Indonesia (GAF-ID) - Internet-based behavioral activation intervention for depression in Indonesia: study protocol for a randomized controlled trial. Trials; 2016; 17: 455.

15. Alfian R. Layanan Pesan Singkat Pengingat untuk Meningkatkan Kepatuhan dan Menurunkan Tekanan Darah Pasien Hipertensi di RSUD Dr. H. Moch Ansari Saleh Banjarmasin. Media Farmasi; 2014; 11: 189-96.

16. Kafiar R. Pengaruh SMS Reminder terhadap Perubahan Perilaku Kepatuhan Pengobatan ARV pada Pasien HIV AIDS di Puskesmas Timika Papua. Program Magister Keperawatan. Yogyakarta: Universitas Muhammadiyah Yogyakarta; 2016.

17. Rahmah P. Pengaruh Intervensi SMS (Short Message Service) terhadap Kepatuhan Pengobatan dan Gaya Hidup Pasien Diabetes Melitus di RSUD DR. M. Ashari Pemalang. Fakultas Farmasi. Purwokerto: Universitas Muhammadiyah Purwokerto; 2016.

18. Edejer TT-T. Disseminating health information in developing countries: the role of the internet. BMJ : British Medical Journal; 2000; 321: 797-800.

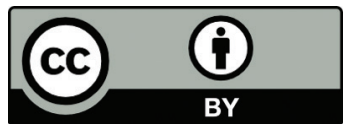

This work is licensed under a Creative Commons Attribution 